\title{
A Raised \\ Bonnet on the \\ Lost Highway: \\ Whither \\ Les Cleveland?
}

Six years have passed since Les Cleveland's death in 2014 and next year will be the centenary of his birth. Recently, there have been two warm personal accounts of Cleveland the man and the respective writers' personal relationships with him. ${ }^{7}$ However, amongst the obituaries published shortly after his passing, there was a tribute by Peter Ireland in which he claimed, "the reception of his work in the present day remains stalled", and he concluded that although his "adventuring has ended.. his work's has just begun." 2 I would concur with the first of these claims and agree to some extent with the second. In what follows, I want to address possible reasons for this stalling by returning to the question of Cleveland's place in photographic history and reexamining the significance of his framing within public exhibitions and related critical publications. I will argue that his position within local photographic history and intellectual culture in general needs to be clarified; and that the nature of his photography needs to analysed in more than purely local terms.

Keywords: \#Cleveland \#New Zealand \#Photography \#History 
Les Cleveland's public critical reception and reputation as a photographer began with his inclusion in the exhibition Witness to Change: Life in New Zealand - John Pascoe, Les Cleveland, Ans Westra Photographs 1940 - 1965, curated by Janet Bayly and Athol McCredie, which toured throughout New Zealand in the period from 1985 to 1987. Each of the three photographers featured in the exhibition was represented by 12 photographs, all of which were reproduced in the exhibition catalogue; and further images were included in albums and as in-text illustrations. All of the 12 Cleveland exhibition prints were taken in the second half of the 1950s, eight of them in the Westland region, accompanied by four studies of wooden buildings in Wellington. The three photographers, each of whom represents a decade, are positioned as transitional or pioneer figures that paved the way for the generation of New Zealand art photographers who emerged in the late 1960s and 1970s. Thus, the exhibition and catalogue can be seen as the first part of a two-part project, the second being Athol McCredie's book and accompanying Te Papa exhibition, The New Photography: New Zealand's First-Generation Contemporary Photographers (2019). The importance of Witness to Change's three photographers is seen to lie in the straight documentary qualities of their work, their freedom from camera club conventions, and their independent spirit. However, in his essay on Cleveland, Athol McCredie differentiates him from Pascoe and Westra by referring to his alleged "lack of interest in photographic aesthetics". 3 This is a claim I will contest over the course of this essay by examining a selection of Cleveland's photographs and demonstrating that these images are open to an aesthetic reading.

The next stage in the formation of Cleveland's critical reputation was, of course, his first and so far only solo exhibition in a public art gallery: Les Cleveland: Six Decades - Message from the Exterior (1998). The period in which this exhibition was staged (1 August - 11 October 1998 ) is the only time in its history when all of the exhibition space in the City Gallery Wellington was given over to photography. In addition to the Cleveland exhibition, the gallery also hosted exhibitions of the work of Lee Miller and Ansel Adams, and these three exhibitions of black and white photography ran in conjunction with the inaugural Wellington Fotofest. However, in contrast to the two exhibitions from overseas, which were purely photographic, the local exhibition embraced other, non-photographic dimensions of Cleveland's work, in both the exhibition space and in the pages of the accompanying publication.

As exhibition curator and publication editor, I wished to address the full spectrum of Cleveland's creative practice, not just his photography, even though 87 framed photographs formed the core of the exhibition. Accordingly, I incorporated the following extraphotographic components within the exhibition: a soundtrack composed of songs from Cleveland's published albums, which played continuously in the exhibition space ${ }^{4}$; a selection of published magazine (e.g. New Zealand Listener) and book (The Silent Land) page spreads, which were housed in two vitrines, placed in the centre of the gallery; outside the gallery space, The Ghost Town Ball - Waiuta (1986), a National Film Unit documentary narrated by Cleveland, was screened daily at $1 \mathrm{pm}$ in the City Cinema, as was a compilation from the TV2 documentary series Not so Long Ago (1980, written and presented by Cleveland), daily at $2.05 \mathrm{pm}$. There was also an extensive programme of events throughout August and September: two slide talks by Cleveland himself (one on "The story behind Message" and another on "Utopian New Zealand"); my Gallery talk on works in the exhibition; and a performance of New Zealand songs and ballads by Les Cleveland with students from Toi Whakaari New Zealand Drama School and their music tutor Laughton Patrick.

In my original proposal I envisaged an exhibition of 150 photographs and other creative artifacts, an accompanying catalogue, and a four-page brochure (free to the public). ${ }^{5}$ When it became clear that the gallery's project budget could only accommodate the four-page brochure, I prepared a further proposal for publication funding, which the gallery submitted to Creative New Zealand. The success of this application then led to a publishing partnership with Victoria University Press, quite appropriately given that Les Cleveland was a former Reader in Political Science at VUW. ${ }^{6}$ There were two main reasons why I felt that a substantial monographic publication was an essential part of the project. Firstly, this was a once in a lifetime moment to address the full range of Cleveland's achievement. Given his advancing age and the fact that it would certainly be a long time before there would be an opportunity to mount another solo exhibition, it was important to get it right. Secondly, the ephemeral nature of exhibitions and the uncertainty about touring prospects made it imperative to have a more permanent record.

One of the aims of the exhibition was to emphasise that Cleveland was still very much a practising photographer, rather than someone whose work was enclosed within the period stretching from the early 1950s until the mid-1960s. In an end note in my essay for the book, I argued, "An unintended consequence of his positioning in Witness to Change may have been to associate Cleveland exclusively as a 
photographer of 1950s Westland and Wellington in the minds of some viewers." ${ }^{7}$ It is true that in the near thirty-year period from the mid-1960s to the mid-1990s Cleveland did little photography, as he was primarily focused on the teaching, researching, and writing commitments of his academic career. However, following his retirement from VUW, he returned to photography in earnest from the early-1990s onwards, not only making images in Wellington but also in various parts of the USA in the course of two trips to that country (1994 and 1996). Twentyfour of his American images were included in the exhibition and 17 of them in the book, many in juxtaposition with his earlier New Zealand photographs, in order to register the continuity of his thematic interests in 'frontier' imagery and the representation of relics and ruins.

As was the case with the exhibition, the aim of the publication was to address the full range of Cleveland's creative practice. His photography was represented by a selection from the exhibition: 56 plates in the central section of the book; a further two plates in the essays by Peter Turner and Laurence Simmons; and numerous gutter illustrations throughout my essay, the biographical chronology, and the bibliography. In addition, I included several examples of Cleveland's creative writing: a short story ("A Course in Survival"); and two poems, one published previously ("Hearths"), and another hitherto unpublished ("Enchantment at Barn Bay"). The overarching editorial purpose behind the three essays was to provide balanced discussion of Cleveland's work from a variety of angles. My essay addresses all major dimensions of Cleveland's creative and intellectual practice: photography, music and musicology, and writing. Peter Turner's essay is a personal reflection on the significance of the photographer's work; ${ }^{8}$ whereas, Laurence Simmons examines the relationship between documentary and poetics by means of a close reading of a single Cleveland photograph ("The European Hotel"). ${ }^{9}$

An overarching purpose animating my essay for the publication was to locate Cleveland's creative project within the intellectual field of New Zealand culture. These concepts are derived, of course, from Pierre Bourdieu. There wasn't the space within the set word count of the essay to explicate them, but I would like to say something about them here. Cleveland's two main creative practices were photography and popular music (as both practitioner and musicologist). Certainly in the 1950s and 1960s, neither of these artistic forms qualified as "consecrated arts" positioned within "the sphere of legitimacy claiming universality". Rather, they fell within "the sphere of what is in the process of legitimation". ${ }^{10}$ In 1958, the local painter and photographer
Eric Lee-Johnson put it this way, "Among the fine arts, photography occupies a position midway between doodling and washing the dishes [...] Let's face it: still photography as an art form isn't taken too seriously, and the photographer despite and perhaps because of the efforts of the photographic societies, has little standing as an artist ..."11

Within the New Zealand context the achievement of John Pascoe, Les Cleveland, and Ans Westra was to pave the way for the emergence of 'serious' art photography within the network of art galleries and publications beginning to populate the intellectual field from the 1970s onwards. Such, anyway, is the claim of Witness to Change and, by extension, The New Photography. Prior to this period, venues for the publication of photography and indeed popular song were extremely limited. The fact that a handful of Cleveland's photographs "were published in that registered vehicle of literary nationalism, Landfall", as David Eggleton puts it, does not mean that they fitted seamlessly into that journal's cultural project. ${ }^{12}$ The broad question to ask here is what degree of unconscious consensus was there among Landfall contributors of the period and what degree of dissensus? I would suggest that a reading of Cleveland's MA research paper ${ }^{13}$, his letter in response to an essay by Rob Wentholt ${ }^{14}$, and the thematic and formal qualities of The Silent Land ${ }^{15}$ point in his case to a considerable degree of dissensus within the consensus, to invert Bourdieu's categories.

In his essay on the $19^{\text {th }}$ century Nelson-based photographic enterprise of the Tyree brothers, Cleveland characterizes photographers as "popular artists" and commercial photography in particular as "a form of mass communications". He refers to New Zealand as an "export cultural fragment" that is still linked to the "parent whole", and asks, "Given the essentially imitative and dependent nature of the New Zealand sub-culture, what prospects has the writer, photographer, painter got for fashioning a genuine native idiom or a personal style that will express the differences and the tensions between the export cultural fragment and the parent whole?"16 To a large degree, this echoes a programmatic statement made by Charles Brasch in 1947, “... colonies begin as crudely broken-off fragments of the parent society; the impulse behind their foundation generally includes an urge to realize more fully some part of the implicit ideal purpose of that society ... the colony once established easily drifts into a stagnating existence as a dull provincial reflection of the parent society ..."17 This congruence could be said to represent the "consensus within the dissensus" or, to put it another way, "the unconscious consensus on the focal points of the cultural field". ${ }^{18}$ But because of Cleveland's own creative investment in non-consecrated 


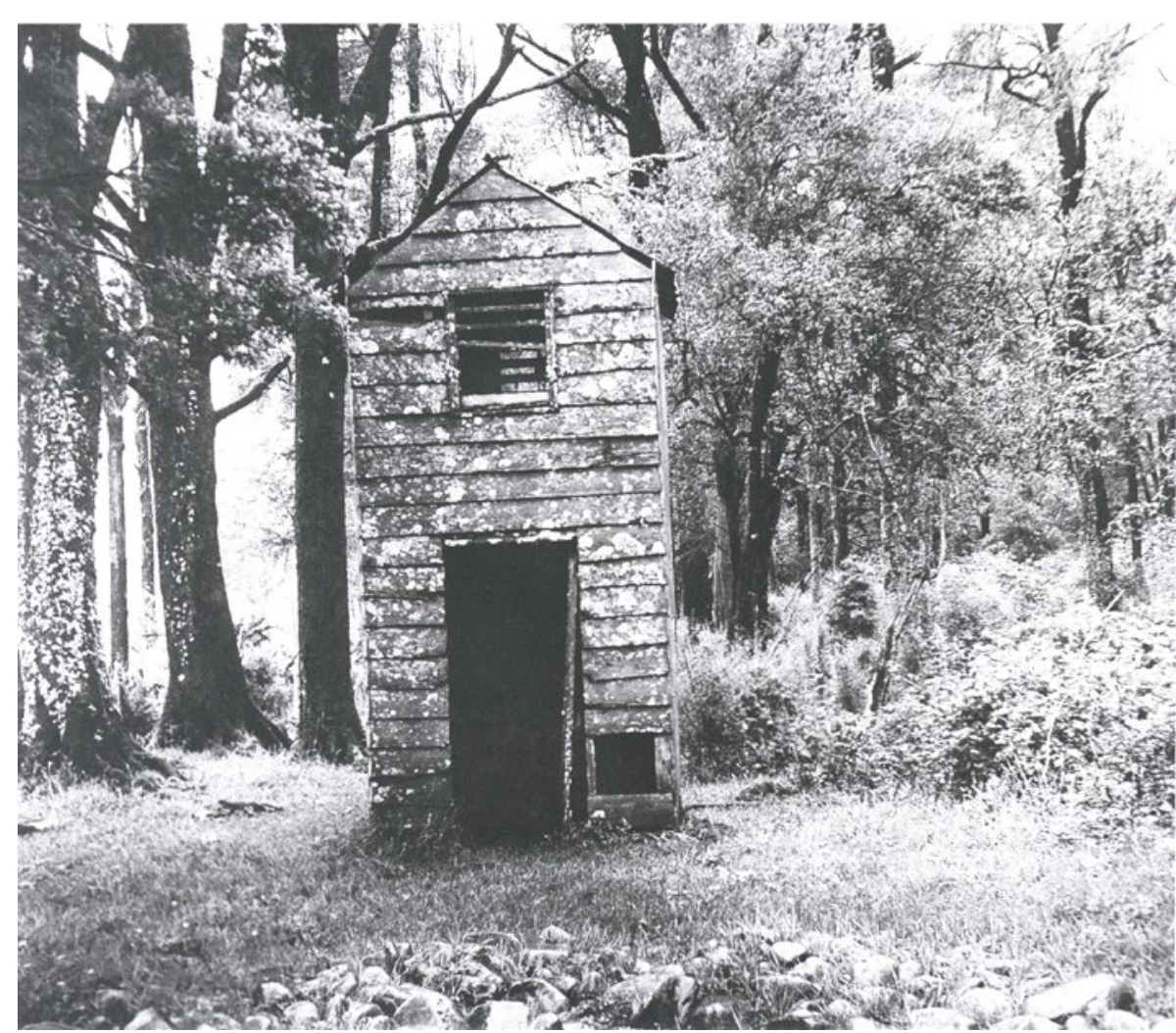

Figure 1. Les Cleveland, "Farmer's killing shed at Haupiri, Westland, 1957". arts and his intellectual investment in the study of mass media and popular culture, his dissensus within the consensus points in a very different direction to the literary nationalism of the Landfall project.

In the same year that Les Cleveland: Six Decades - Message from the Exterior (1998) was exhibited at the City Gallery Wellington and Victoria University Press published the accompanying book, VUP also published Stuart Murray's Never a Soul at Home: New Zealand Literary Nationalism and the 1930s. The cover of Never a Soul at Home carries a reproduction of Cleveland's photograph "Farmer's killing shed at Haupiri, Westland, 1957". Regardless of who chose this image for the cover, publisher or author, a clear connection is made between the New Zealand literary nationalists of the 1930s and beyond and Les Cleveland's 1950s photographs. This is arguably the most powerful and suggestive of Cleveland's 1950s Westland photographs, which, in the particular move made here, propels the image back towards what Walter Benjamin calls cult value ${ }^{19}$, and it is undoubtedly a good fit with the book's title and its central thematic. However, it does not thereby follow that Cleveland's project can be assimilated to the literary nationalism that began to take shape in the 1930s and had achieved a certain high cultural hegemony by the time he made the photograph in question.

A more explicit link to literary nationalism came eight years later in Into the Light: A History of New Zealand Photography when David Eggleton placed Cleveland amongst "The Nationalists" in the fourth chapter of the book ("Dominion"), summing him up as, "a nationalist who was 'out' about it." ${ }^{20}$ It is never made clear in what way the disparate group of photographers assembled in this chapter all share some undefined investment in a nationalist discourse. Nor, for that matter, how Cleveland is more "out" about his alleged "nationalism" than, say, Leslie Adkin. Of the three Cleveland photographs reproduced in the book, the first is none other than "Farmer's killing shed at Haupiri" (Fig. 1), incorrectly dated 1956. Eggleton then goes on to make a direct link between New Zealand literary nationalism and Cleveland's photographic book, The Silent Land (1966): “ . . . the actual title is meant to remind us of Charles Brasch's 1940 poem of the same name and its message: "the plains are nameless and the cities cry for meaning." 21 There are a number of reasons to be sceptical about this claim. Firstly, when I asked Les Cleveland if the title of his book makes reference to Brasch's poem, his response was curt: "no". A more compelling because less anecdotal reason is Cleveland's summation of literary nationalism (not specified as such): " these various literary theories were largely some sort of intellectual rubbish." ${ }^{22}$ But perhaps the most cogent reason 
to doubt an affinity between Brasch and Cleveland's poetic artifacts can be found by means of a close comparative reading of the two works. Brasch's poem was written in the 1930s and published in his collection The Land and the People (1939). ${ }^{23}$ The first verse asserts the absence of a cultural patina on the New Zealand landscape. The second registers the brute facts of the natural landscape. The third sees the country (both rural and urban) as unspoken and unwritten ("The unproved heart still seeks a vein of speech"). The fourth emphasises "quiet" and "solitude". The remaining three verses point towards a resolution of the dilemma, whereby solitude will be overcome in a "homecoming" within which "He" will "hear the sea talking" and, in the memorable final line, the angel will sign "life's air with indefinable mark". Obviously, a bald paraphrase such as this does not do justice to the poetic qualities of Brasch's verses. Nonetheless, for comparative purposes it does indicate the near timeless nature of the poet's Olympian view onto the landscape and its would-be occupants, articulated in a formal tone that borders on the portentous.

When we turn to Cleveland's work of the same name (not a poem as such but an interaction between image and text), the differences rather than any alleged similarities are immediately apparent. Following the establishing shots of two very specifically identified West Coast landscapes, we encounter a horizontal image shot from a low angle of two trampers traversing hilly terrain (via the leading line of a ridge of rock), which is echoed in the ninth photograph of one of the trampers walking across a bridge "Towards a silent land"; and over the page a double-page spread featuring two photographs of dead trees is headed "A SILENT LAND". I would stress that the land depicted here may be silent but not only is it not timeless or generic but also the figures which journey across it are fully embedded and at home within it. Above all, though, this is a thoroughly historical and social landscape. The photographs register both the traces of the past and signs of life in the present (all the photos were shot in the 1950s and early 1960s), just as the verse too ranges across "the wreckage of the past" ("a reassuring heroic past") to "An excluded present", and on to "labyrinths of future speculation". I will not persist here with a full reading of The Silent Land because I have already done so in Message and the reader is referred to that. ${ }^{24}$ Suffice it to say, my comments here provide sufficient evidence to demonstrate the chasm that separates Brasch's "The Silent Land" from Cleveland's.

Although, on the whole, the exhibition and the publication received favourable critical appraisal, this often did not extend to the photographs made in America. Paul Thompson, in a review of the book, asserted, ". . . the images of New Zealand in the 1950s and 60s... are the strongest in the book ..."; and he went on to speak against "trying to position Cleveland internationally". ${ }^{25}$ Neil Penman, also in a review of the book, stated, "The 17 American pictures . . . rather lack the strength of the New Zealand photographs, although several are worthy of attention." 26 Justin Paton was rather more forthright in his criticism of this aspect of the book's editorial choices: "Cleveland's midcentury works are pointlessly rhymed with recent photos that simply aren't as telling". ${ }^{27}$ Underpinning these comments, especially Paton's, is the assumption that the exhibition (and perhaps, by implication, monographic exhibitions in general) should have been a cherry-picked display of the artist's greatest hits. In other words, an amplification of the temporal (1950s) and geographical (Westland and Wellington) choices exemplified in Witness to Change. By contrast, in his review of the book, Peter Ireland refers to "...the uniformly excellent reproductions in an unusual sequencing that seems to mirror the random mechanism of memory..." ${ }^{28}$ And Damian Skinner, in a brief but perceptive exhibition review, discussed Cleveland's work in relation to the exhibition's curatorial strategies: "the emphasis on systems of signification . . complicates 1950s images that might otherwise be taken as a unique and authentic New Zealand. Here the difference between Las Vegas and Wellington is rendered closer and more intimately than we might expect." 29

The view that Cleveland's American photographs and his interest in aspects of American culture in general are marginal to his photographic achievement and his wider intellectual accomplishments is simply unsustainable. To begin with, recall that in the late 1950s the working title for the project that was eventually published as The Silent Land was "The Frontier". Although to my knowledge he never directly cited it, there is a clear echo here of Frederick Jackson Turner and his influential paper "The significance of the frontier in American history" (1893), which at some level can be seen to have provided a prompt for Cleveland's visual and literary representation of Westland in The Silent Land. Secondly, in my analysis of The Silent Land in Message, I argued that it differs markedly from other New Zealand photographic books of the period and since, and that it is more profitably seen as doing something comparable to the American photographic book Land of the Free (1938). ${ }^{30}$ The photographs in Land of the Free are mostly from the photographic archive of the Resettlement Administration, a Depression era New Deal initiative that immediately preceded the Farm Security 
Administration, whereas the text is a long poem by Archibald MacLeish. I argued that in both books the relationship between the images and the text is analogous to the image track and the soundtrack (voice over) of a documentary film, specifically American and British documentary film making of the 1930s. Another point of connection between Cleveland and American sources can be found by examining his essay on the Tyree brothers Nelson-based photographic business of the late $19^{\text {th }}$ and $20^{\text {th }}$ centuries. His interest in the Tyrees began in the mid-1960s when he put together "A memorandum in information gathered to date in the course of biographic research". ${ }^{31}$ But it wasn't until 1979 that he published an article on this topic. In the article he refers to the New Zealand frontier ("a Pacific frontier") characterized by an urban architecture of wooden facades. He draws attention also to three factors that structure New Zealand history: the natural environment / geographical location (in other words the frontier concept); relationship to the parent culture (i.e. the fragment concept); and Polynesian culture as a "modifying influence". ${ }^{2}$ As he works his way through the essay, he draws on historian Daniel Boorstin's The Americans: the Democratic Experience (1974) and political scientist Louis Hartz's The Founding of New Societies (1964). Taking into account these connections and resemblances to American history, theory, and culture, it is not surprising that in the period following his retirement from VUW, Cleveland would be interested in taking up a Smithsonian fellowship in the USA, and that once there he would be interested in photographing parts of the country.

One reviewer of Message from the Exterior (the book) remarked that the wide geographical and temporal range of the plates made the book "rather chaotic". ${ }^{33}$ Another considered that the inclusion of Cleveland's poems and fiction, along with the commentary on popular song made "the book feel overly rambling". ${ }^{34}$ The first statement is related to the familiar and uncontroversial claim that the 1950s/60s photographs are Cleveland's strongest. The second, however, seems unwilling to accept one of the premises of the project: viz. that Cleveland is not a medium specific artist or, indeed, intellectual but rather a multi and interdisciplinary one.

Nonetheless, the word "rambling' inadvertently points to a feature of the book that mirrors a quality in Cleveland's practice. In an interview-based profile, published just prior to the opening of Message, Cleveland says, "I'm an observer who just flits about and comes up with perspectives on a life journey." ${ }^{35}$ In a UK context, a rambler is someone who traverses landscapes of varying degrees of wildness with varying degrees of planned precision, which is something that the tramper/ mountaineer Les Cleveland did throughout his life. But he might also be seen to have done so across the cultural landscape as well. Furthermore, someone who "flits about" sounds rather like an urban flâneur engaged in a form of drifting across the byways and through the backstreets of the city. Someone like the German writer and translator Franz Hessel who, according to Walter Benjamin, treated "the city as a mnemonic for the lonely walker", and "... would be happy to trade all his knowledge of artists' quarters, birthplaces, and princely palaces for the scent of a single weathered threshold or the touch of a single tile ..."36 In short, Cleveland can be seen to be something of a psychogeographer. In this he resembles Eugene Atget. In many respects he is to the Wellington of the $1950 \mathrm{~s} / 60 \mathrm{~s}$ what Atget was to the Paris of the early $20^{\text {th }}$ century. Take, for instance, the photograph "Shop window in Riddiford Street, Newtown, Wellington, October 1957" (Fig. 2) and place it beside Atget's "Boulevard de Strasbourg, corsets, Paris, 1912" (Fig. 2a). Cleveland's camera is closer to the shop window, and thus reveals more details of the tags on the garments, but like the Atget image its slightly oblique angle brings the display vividly to life. Moreover, the composition of the Cleveland image makes very good use of horizontal and vertical leading lines. Thus, what is at work here is not just a matter of a shared thematic interest but also involves an affinity in formal terms.

A further point of connection between the two photographers can be found in the representation of urban workers in situ. Cleveland's precisely located and dated photograph, "Workman cleaning points in tramlines at corner of Manners and Willis streets, Wellington, 16 September 1957" (Fig. 3), is an outstanding depiction of a stooped tramways worker captured at work in the middle of an inner city road. $\mathrm{He}$ is positioned in the frame at the top of a shaded area bordering on an illuminated section of the street. The chiaroscuro quality of the image is further complicated by the curvilinear pattern of the tramlines. Atget's "Pavers, Paris, 1899-1900" (Fig. 3a) is a closer shot of men at work in the city, structured by a contrast between a foreground that captures the workers' movements in sharp focus and a blurred background involving a passing horse and rider; although, unlike the Cleveland photo, Atget's has posed the central figure.

Turning now to a more recent Cleveland photograph, one shot in the United States, I will compare it and the circumstances within which it was taken to the other photographer with whom he has the most affinity. The photo in question is "Mother and Daughter, New York 1994" (Fig. 4), which clearly was made within the confines of a mode of public transport, most probably the New York subway. This is a balanced 


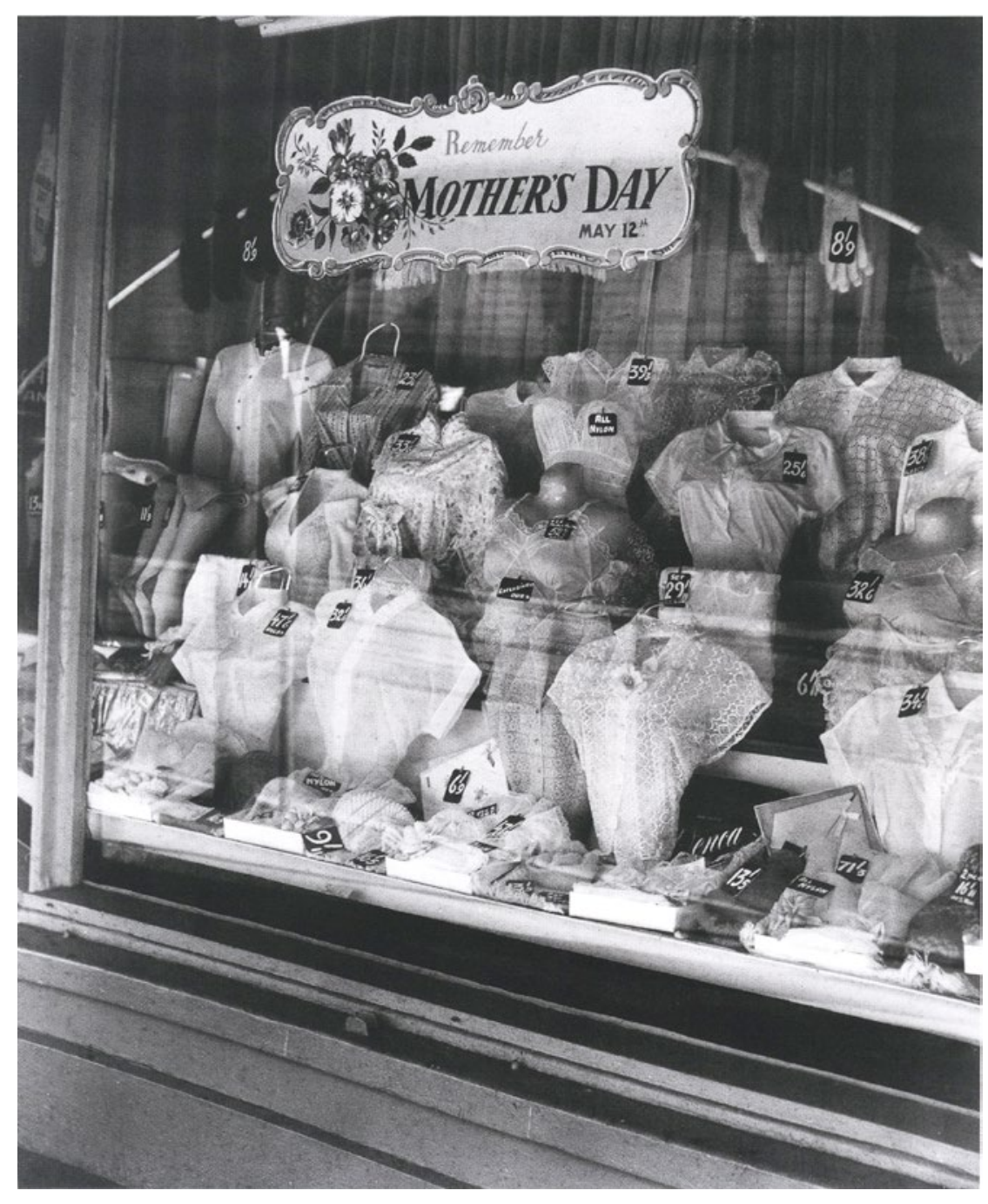

Figure 2. Les Cleveland, "Shop window in Riddiford Street, Newtown, Wellington, October 1957".

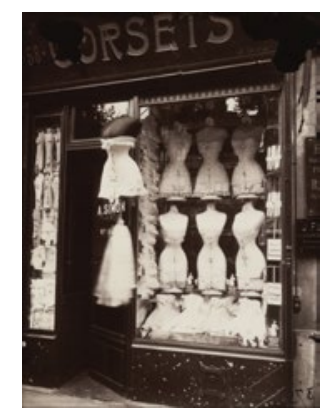

Figure 2a. Eugene Atget, 'Boulevard de Strasbourg', Corsets, Paris, 1912. composition in which the picture plane is bifurcated by a central pole, which the daughter grips. The centre of attention is an arrangement of hands and faces and the diagonal gaze of the two figures seems to mimic the implied motion of the train. Moreover, the viewer's eye is drawn to the contrast between the open and closed eyes of the daughter, emphasized by the position of her elongated middle finger just below the closed eye. This photograph can be compared with an untitled study by Walker Evans, one of many taken on the New York subway between 1938 and 1941. ${ }^{37}$ In his random journeys across subterranean New York, Evans worked with a concealed camera to capture travelers unawares, lost in their thoughts. In the particular Evans photo, we also see two women, but they are of a similar age and the direction of their gazes is in the opposite direction to the Cleveland image (i.e. leftwards). The Evans photo, too, is bifurcated, in this instance by a central vertical strut behind the head of one of the women, and again the direction of the gazes rhymes with the movement of the train. Also, a similar kind of blanked out introspection is evident in both photographs, although more pronounced in the Cleveland. However, a photograph such as this is not the first that comes to mind when considering points of connection between Cleveland and Evans. Studies of vernacular architectural buildings, especially wooden ones, are the more obvious candidates. Nevertheless, in the example just discussed an affinity is clearly there.

Mention of vernacular wooden buildings reminds us that there are many fine examples in the pages of Evans's American Photographs (1938). If Cleveland's comparable photographs had found an equivalent home it might have been called "Wellington Photographs". Unfortunately, such a book, which might have done for Wellington what The Silent Land did for Westland, does not exist. Interestingly, a book of photographs we do have from the same broad period as Cleveland's 1950s/60s Wellington photos seems on the surface to cover similar territory. Vintage Wellington (1970) by architect Charles Fearnley is a photographic record of a wide range of Wellington's distinctive buildings, accompanied by lengthy, detailed captions. ${ }^{38}$ Fine as Fearnley's pictures are, they are very much architectural records in a plain documentary style. To a degree, Cleveland's style is also plain and documentary in character (the appropriate term here is vernacular style), but despite the claim that he had little interest in aesthetics there is a poetic quality to it that transcends mere documentation. There is also invariably the suggestion of traces of the historical and social transactions between the urban environment and its inhabitants. If Les Cleveland had made a book of Wellington photographs, it is likely 


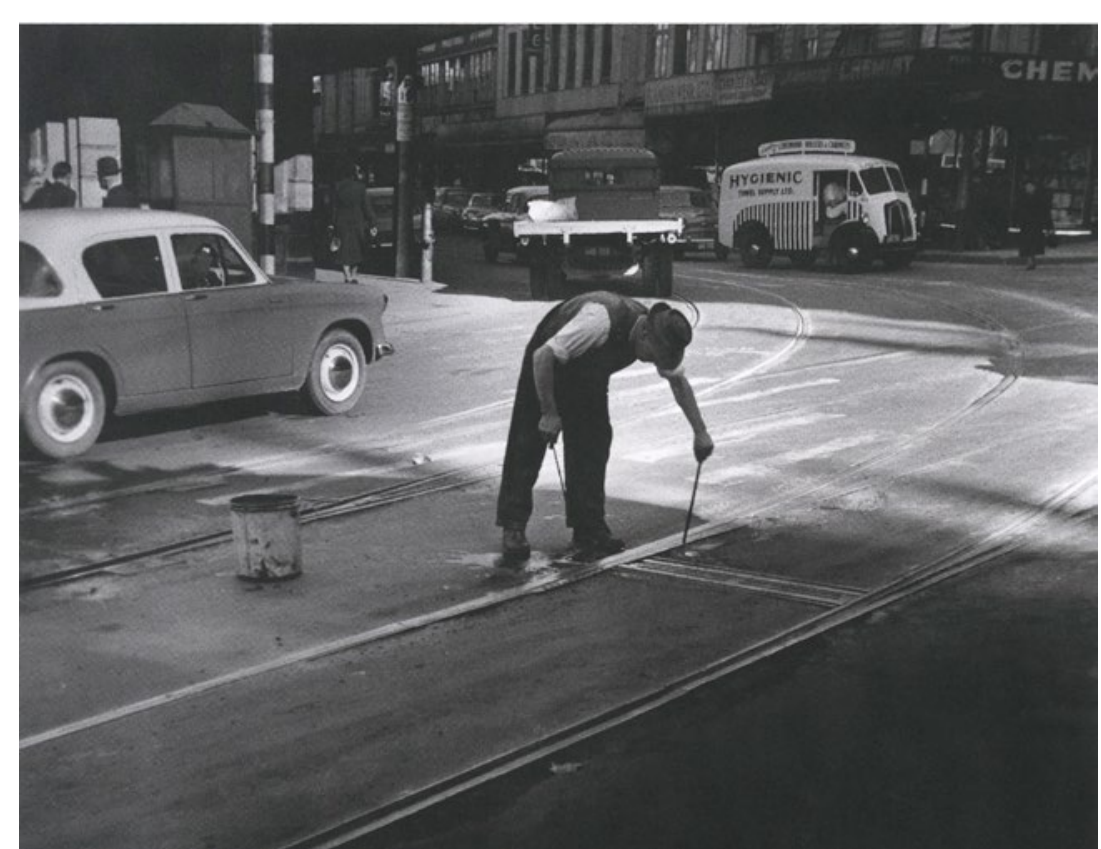

Figure 3. Les Cleveland, "Workman cleaning points in tramlines at corner of Manners and Willis streets, Wellington, 16 September 1957".

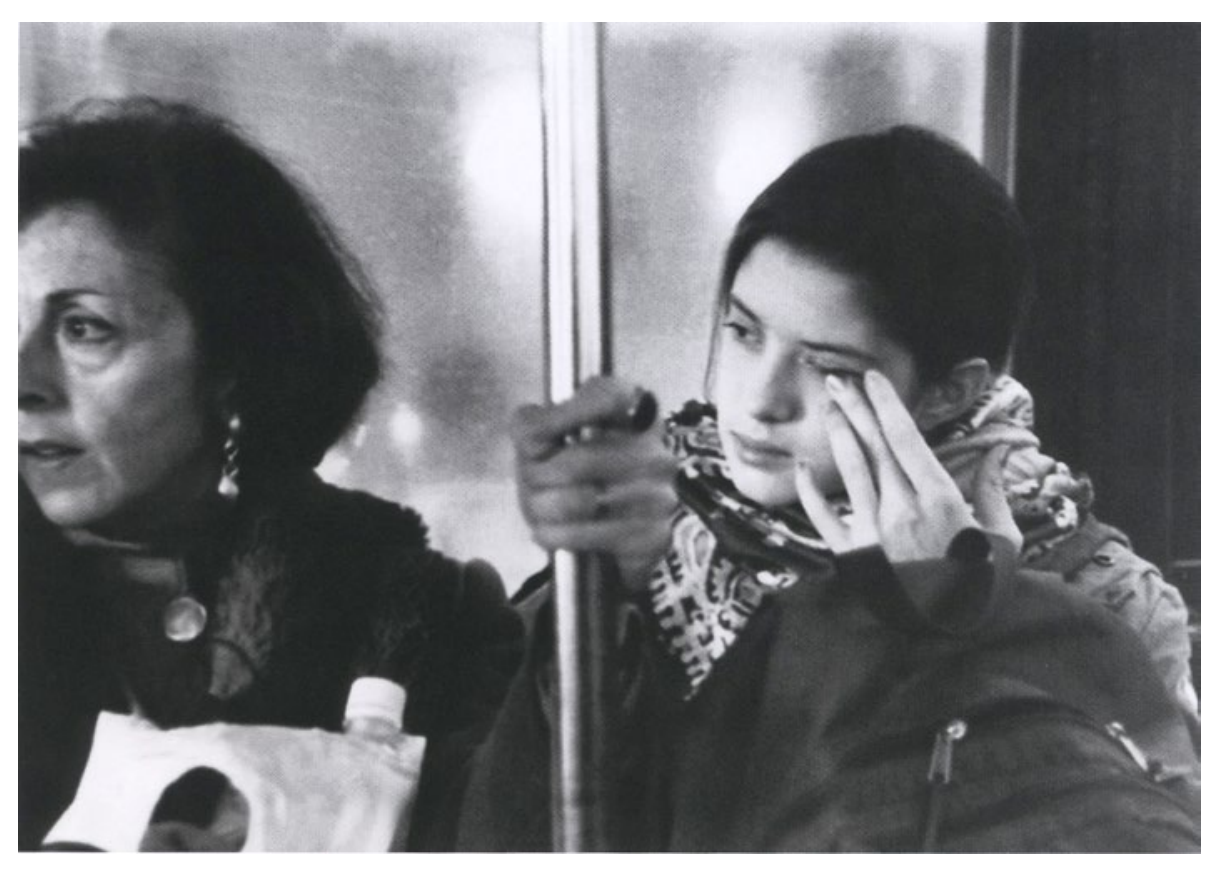

Figure 4. Les Cleveland, "Mother and Daughter, New York 1994". Image from Les Cleveland: Six Decades - Message from the Exterior, published by City Gallery Wellington and Victoria University Press, 1998

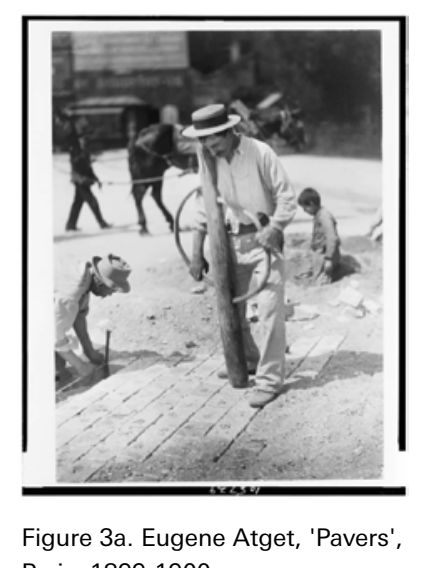
Figure 3a. Eugene Atget, 'Pavers',
Paris, 1899-1900. 
that he would have also composed a verse or prose text to accompany them, as he did with The Silent Land. And it is also likely that he would have included some of the photographs he took in the transformed/ transforming Wellington of the late $20^{\text {th }}$ century and the new millennium, thereby matching elegiac qualities with criticism of the imperatives of thoughtless development and 'progress'. A glimpse of what such a book might have been can be found in "The Harrowing of Te Aro: a Photo Essay". This photo essay contains three photographs of Wellington in the 1950s and one from 2002 (Apartments in Courtenay Place"). In an accompanying text Cleveland states, "Te Aro has been devastated by the forces of modernity", and he laments, "Metropolis is triumphant in Neverland". ${ }^{39}$ Five years later, Cleveland presented a fuller version of this nascent project in "The Secret City - 35 Photographs", his final solo exhibition at the Peter McLeavey Gallery (14 March - 7 April 2007). In her biography of the dealer, Jill Trevelyan states that McLeavey considered the exhibition to be one of the ten most important he ever mounted. And she quotes him thus, "... it was an anthem; a love song; a sermon; and maybe a rant, to or about our city ... at 86 [Les] still has fire in his belly, and can shake his fist at the powerful, the greedy, and the apathetic." 40

In the early 1990s, Alistair Morrison pithily and memorably described Les Cleveland as "a good keen man with a PhD"41, and since then various commentators have repeated this phrase to such a degree that it has become the standard way to sum him up..$^{42}$ There is an unavoidably masculinist connotation to the phrase, with the emphasis falling on the Crumpian first half. And certainly there are plenty of photographs that can be made to fit this image. Yet there are also many that depart from it and belie this now rather reductive view. I will discuss a few of them in detail now.

One of the most striking 1950s/60s photographs included in the exhibition was not made in either Westland or Wellington, but rather in the central North Island: "The Patient, Mt Ruapehu 1962" (Fig. 5). Indeed, such is its power of suggestion that I chose it as the cover image for the exhibition catalogue. The photograph's setting, subject matter, and narrative content can be summarized as follows: a young woman has had a skiing accident on the slopes of Mt Ruapehu and is now being attended to by three people (presumably older men, but not necessarily) in an unspecified interior. There is a marked difference between the two iterations of the photograph. Whereas the exhibition print/book plate was printed from the entire negative, the book's cover image was cropped. Both iterations revolve around the two most expressive features of the human body: the face and the hands. In the exhibition print, arms

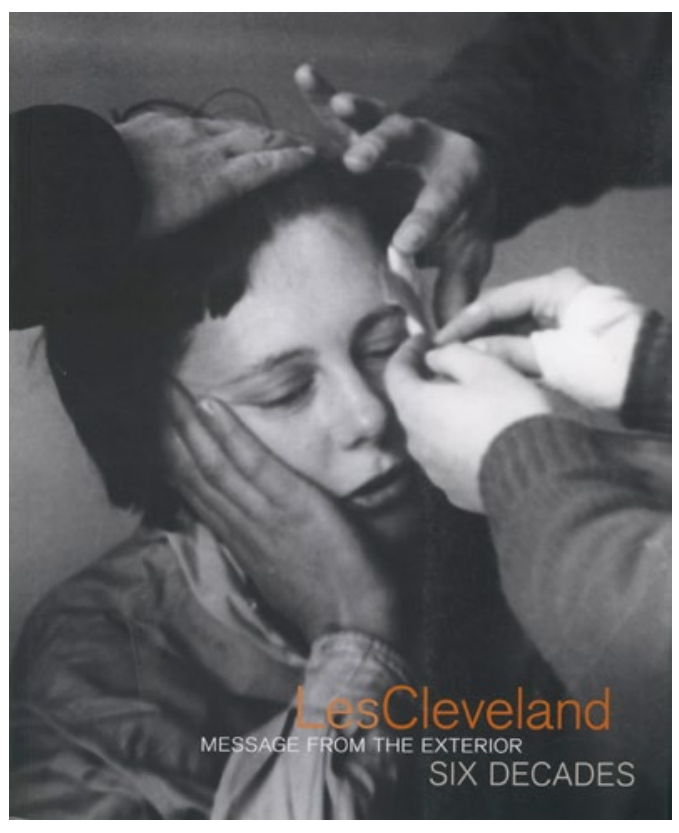

Figure 5. Les Cleveland, 'The Patient, Mt. Ruapehu 1962 '. Photograph used on the cover of the catalogue/book Cleveland: Message from the Exterior. Six Decades. Image courtesy of Victoria University Press.

(as opposed to just hands) converge on top of the young woman's head and in conjunction with her body form something of a tau cross shape. Two of the hands are applying a dressing to the "patient's" face, while another performs a comforting and steadying action on the top of her head. There is an elaborate horizontal but slightly diagonal interplay of arms across the picture plane, which creates three areas of negative space in the composition as a whole. The central subject's closed eyes and hand supporting her cheek are also important elements in the composition and the mood it creates. Interestingly, the detail of the chained pole attached to the left-side figure and his black clothing impart something of a liturgical feel to the picture.

In the cover iteration of the image, what little wider context there is in the exhibition print is removed and the emphasis falls firmly on the symphony of face and hands, which are decisively foregrounded in close up (as opposed to the original's medium shot). And, as this is a book cover image, the photograph is the major element, with the title running across the bottom segment. The key phrase in the title is Message from the Exterior, which resonates with an image that depicts the laying on of hands to the surface of this young woman's head and face. Moreover, 
the quality of tenderness and care is represented in more concentrated form here.

In addition to this photograph's undoubted power, there is another reason why I chose it for the cover, and it is an intertextual one. For me, this photograph brings to mind sequences from one of the great films of the late silent era: Carl Th. Dreyer's La Passion de Jeanne d'Arc (1928). I'm thinking specifically of the scene in which Joan (Maria Falconetti) is being prepared for her execution at the stake, by having her hair cut. There is a similar monochromatic dynamic here involving the interplay of hands in proximity to a close up of the face. Except that the Cleveland image inverts the imposition of the punishment and agony inflicted on Joan to its opposite: the relief of pain and distress by means of care and empathy. What the two images share, though, is the invocation of a 'spiritual' quality, or, in Paul Schrader's terms, transcendental style, a style in which "the immanent is expressive of the Transcendent." ${ }^{33}$ But more than this, "The Patient" speaks to the obligation towards the other that Emmanuel Levinas addresses in his disquisition on "Ethics and the Face". He expresses it in these terms, "The face opens the primordial discourse whose first word is obligation, which no "interiority" permits avoiding". ${ }^{44}$ Thus, within the small and modest confines of "The Patient", there is indeed a profound and lasting message from the exterior.

Having just analysed a photograph that not only appeared in the exhibition but also occupied the cover of the book, I now want to turn to a photograph that played a similar role in the project. The photograph in question is "Woman in Coffee Bar, Herbert Street, Wellington 1959" (Fig. 6), and like "The Patient" its composition is distinctive. In this elongated portrait, a young woman (Lynn Rogers, a Wellington copywriter at the time), shot from a low angle, is stitting on a bar stool. Her body is slightly swivelled and the key features emphasised in her pose, as with "The Patient", are her face and hands. Her confident, and slightly knowing gaze, directed straight at the camera, is offset by the poised but casual manner in which her right hand holds a cigarette while her left hand rests lightly on her thigh. The Café setting is plain and functional but the patterning on the wall mats that dominate the lower two thirds of the photo mingle strikingly with the shadows cast by the struts of the stool. The austerity of the setting rhymes with Rogers's simple monochromatic dress. Her hair is fashionably cropped - think Anna Karina in Jean-Luc Godard's Vivre Sa Vie (1962) from the same period. ${ }^{45}$ Without doubt this is an image of nonchalant elegance. In short, it's a chic pic.

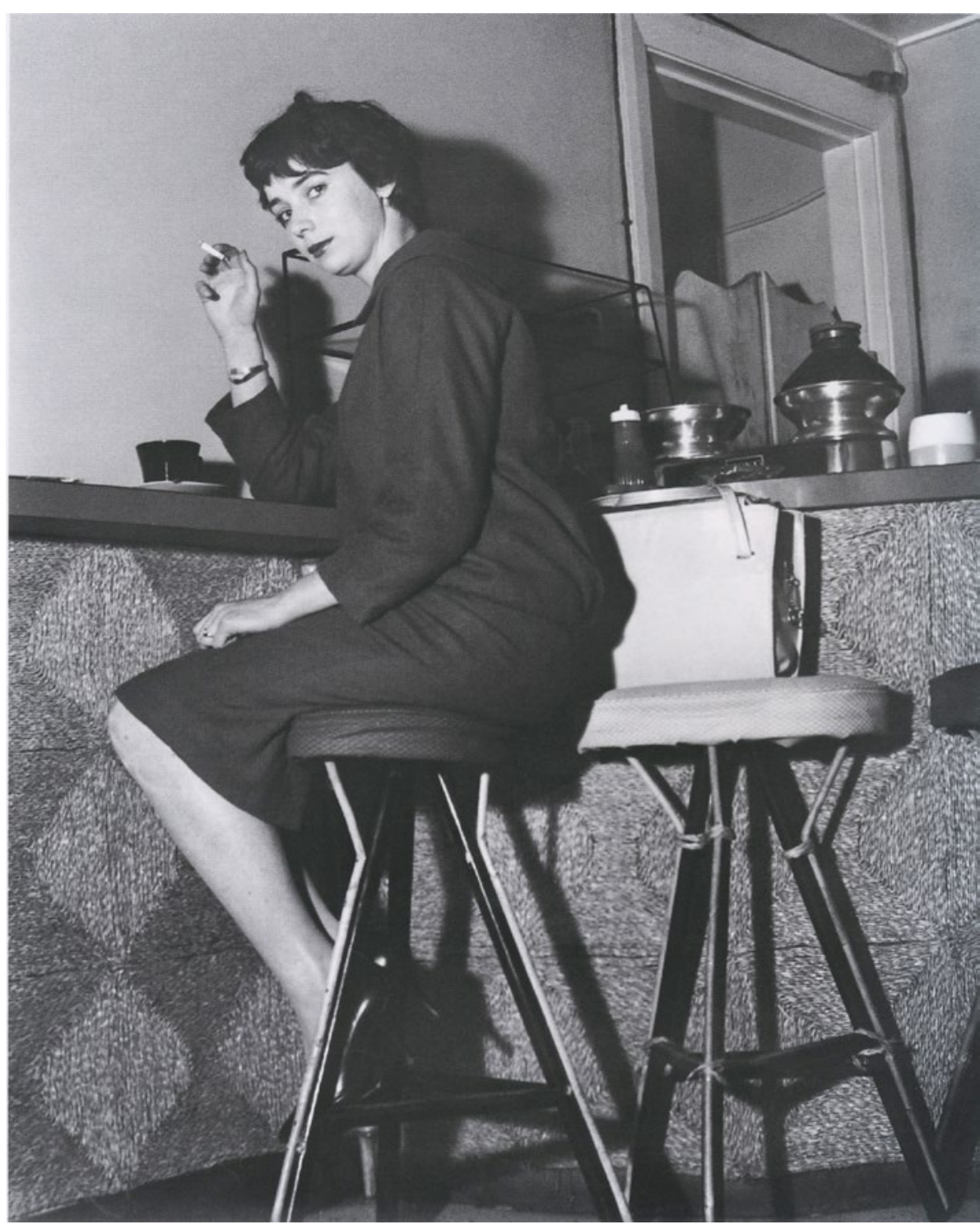

Figure 6. Les Cleveland, "Woman in coffee bar, Herbert Street, Wellington 1959". Image from Les Cleveland: Six Decades - Message from the Exterior, published by City Gallery Wellington and Victoria University Press, 1998 
So arresting is this photo that it was picked as the sole image on the banner announcing the three photographic exhibitions in the central foyer of the City Gallery. And its companion photograph (Rogers walking up the steps of the National War Memorial) was reproduced as a gutter illustration within the Cleveland bibliography at the end of the book.

This photograph formed part of the cover of the August 28, 1959 edition of the New Zealand Listener, which directed the reader to the opening story: "Focus on Hemlines". The photograph I have just examined is printed on page three with the caption, "Short skirts are handier on coffee bar stools". And inside the unattributed article (the bottom of which refers the reader to a forthcoming $Y A / Y Z$ radio programme "Showing the Knee") we read: "For centuries feminine legs have been hidden, with the result that men have striven for the glimpse of ankles revealed by wind or steps." 46 These two photographs are as much a part of Les Cleveland's Wellington as his more well known and celebrated studies of buildings. Furthermore, the fabric and garment captured in them is a long way from the world of Swandri. Thus we are confronted with a hitherto underappreciated phenomenon: Les Cleveland fashion photographer.

A few years prior to beginning work on Message from the Exterior, I co-curated with Virginia Callanan the inaugural exhibition for The Film Archive's exhibition space in The Film Centre: Number 8 / Super 8: Amateur and Home Movie Making in New Zealand (1995). In contrast to film archives in other Western countries, a higher proportion of the collection of Nga Taonga: Sound and Vision comprises amateur and home movies. Accordingly, an exhibition based in this type of film making seemed an appropriate way in which to begin an ongoing exhibition programme at The Film Centre. The films and film excerpts that constituted the heart of the exhibition were organized into ten subject categories. Broadly, the home movies fell within seven distinct groupings: at the beach; on the road; in the camping ground; in the backyard; down the garden path; at the A \& P show; and the main street parade. Whereas the more elaborate or ambitious amateur films were grouped into the categories of drama, local news, and soldiers' wartime experiences. One of the film makers we included in the exhibition, whose work crossed both categories, was W.T. (Wally) Knowles. Knowles, who was based in Dannevirke and was a friend of members of my extended family. He used a Pathe $16 \mathrm{~mm}$ camera and filmed mostly in the greater Hawkes Bay region, although occasionally he operated further afield. He covered street parades and A \& P shows but also made compilations of local news items, most likely modeled on the pathe newsreels made

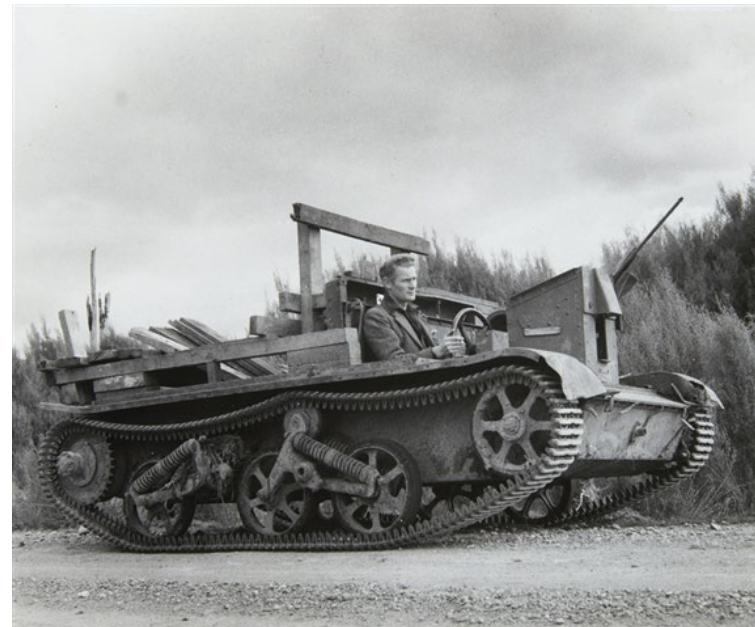

Figure 7. Les Cleveland, “Doug Macalister driving war surplus Bren carrier 1957". Image from Les Cleveland: Six Decades Message from the Exterior, published by City Gallery Wellington and Victoria University Press, 1998 in the UK during the period from 1910 to 1970 . He also made dramas with local actors. I spent some time in his company, had numerous conversations with him, and eventually acquired much of his film making equipment, including his Pathe camera, which I included in a display case in the exhibition space. Knowles was a near contemporary of Cleveland and in many respects my conversations with Les were reminiscent of earlier ones with Wally. But to my mind their main points of connection were their shared interest in camera-generated image making and their intense focus on the particularities of regional New Zealand. Furthermore, there is also the no small matter of their joint investment in amateur modes of engaging with cultural realities. "Amateurism", writes Edward Said, is based in "the desire to be moved not by profit or reward but by love for and unquenchable interest in the larger picture, in making connections across lines and barriers, in refusing to be tied down to a speciality, in caring for ideas and values despite the restrictions of a profession." 47 
If I were to take just one Cleveland photograph that chimes with the spirit of some of the images in the films featured in Number $8 /$ Super 8 it would be "Doug Macalister driving war surplus Bren carrier 1957" (Fig. 7). Here we see Macalister, a bushman at the Kopara sawmill whose informal portrait appears in The Silent Land, driving down a gravel road on the said Bren gun carrier, which has been converted into a vehicle for transporting timber out of the bush. Heath Robinson contraptions comparable to this make appearances in a number of kiwi amateur films. Another point of connection to Wally Knowles and other Number 8 / Super 8 film makers is Cleveland's exhibition at the Peter McLeavey Gallery in 2000, "“Small Towns”: Twenty Two Vintage Photograph". These photographs were taken in the lower half of the North Island and the top of the South Island, mostly throughout the 1950s (there are two from the late 1960s). In a short essay that accompanied the exhibition, Cleveland mentions Skin Hackett who "presides over the transformation of a church into a radiator repair factory" in Watt Street, Wanganui. ${ }^{48} \mathrm{He}$ concludes by listing the factors ("the termites of progress") that have sentenced "some small towns to lingering death".

Like the film excerpts in Number 8 / Super 8, the photographs in Message from the Exterior were also organised into broad categories, six in number: celebration, work, landscape, people, streetlife, and dreams. As one would expect, although based in straight photographic souce material, the final category contained photographs that departed from realism by experimenting with montage by printing from two negatives. "Nightmare on Tongariro 1960", for instance, combines one of Cleveland's studies of Wellington ornamental stone facades with a location photo of the photographer's future wife (Mary Sears), naked on the side of the mountain. Needless to say, the staged narrative qualities of this photograph are a long way from the kind of image that Cleveland is most known for. This picture is something like a strange composite of, say, a less elaborate Jerry Uelsmann photomontage and an item from the rather extensive catalogue of notable photographers' studies of their partners: viz. Alfred Stieglitz and Georgia O'Keeffe; Paul and Rebecca Strand; Harry and Eleanor Callahan; and locally, Hardwicke and Molly Knight.

I have focused on the two major exhibitions of Les Cleveland's work in public gallery spaces. But it is important to remember that in the period stretching from 1990 until 2007, he had five solo exhibitions and was included in a number of group shows at the Peter McLeavey Gallery in Cuba Street, Wellington. Given his strong love of photography and his extensive personal collection of vintage prints, many of them by $20^{\text {th }}$ century masters, it is perhaps not surprising that Peter McCleavey became Les Cleveland's dealer. But there is a further reason. For McLeavey there was something of a parallel between Cleveland and Colin McCahon. At some level, they both can be seen as simultaneously outside and inside the international framework and conversation of their respective mediums. As contemporaries, they both worked away at the bottom of the world, seemingly unconcerned with anything other than the internal imperatives of their own projects and pathways. Clearly, local public exposure and recognition came much earlier for McCahon but his international recognition has been slow to come and intermittent. Les Cleveland's, in contrast, has not even begun.

In the early 1990s, Peter Turner wrote, "Regrettably, I had just finished my History of Photography [1987], otherwise he would have had a place in it", and he asked an important question: "... what is being done, however belatedly, to place Les Cleveland, his peers and successors in the international museum, collection and gallery sphere where they belong?" 49 And in an interview-based article published when Message opened, he is reported thus, "Turner goes so far to consider the fact that Cleveland is virtually unknown outside New Zealand as a cultural crime." ${ }^{50}$ Turner was not the only figure from the northern hemisphere to hold Cleveland's work in high esteem. In the mid-1990s, during a visit to the Peter McCleavey gallery, which was showing some Les Cleveland photographs, Peter introduced me to Manuel Borja-Villel, then director of the Antoni Tapies Museum in Barcelona, who was on a brief visit to New Zealand. When I mentioned I was planning an exhibition of Cleveland's work, he said he would definitely be interested in having an exhibition of the photographs at the Tapies Museum. He summed up his reason as follows: at first sight you think Walker Evans but then you realize there's something else at work. He didn't specify what that 'something else' was but his comment draws attention to the interplay between international and local resonances in the photographs.

Les Cleveland's photography has yet to be exhibited outside New Zealand and even within this country its dissemination has mostly been confined to Wellington (City Gallery Wellington and Peter McLeavey Gallery). Moreover, even though the City Gallery Wellington offered Message from the Exterior to 12 other galleries and museums across the country, all of them declined to take it, giving budgetary considerations or full schedules as the reasons for not proceeding. The local public and private "adventure" of Cleveland's photography made a strong start in the final 15 years of the $20^{\text {th }}$ century but it has 
slowed considerably across the $21^{\text {st. }}$ In this essay, I have argued that the principal reason why the reception of Cleveland's photography

remains "stalled" in the $21^{\text {st }}$ century is because it has become locked within a particular time and within particular places. The dominant view is that he is a "nationalist" whose enterprise can be reduced to a relatively small number of largely 1950s Westland and Wellington photographs, which reveal an essential New Zealand that has long since passed. While in no way denying the power and resonance of these photographs, I have contested this view. Here I have concentrated on discussing photographs that fall outside this limited repertoire and argued that they are just as worthy of attention as his more well-known images. I have also argued that there is more of an aesthetic dimension to his work than some have been willing to contemplate; and that rather than being seen and assessed in purely local terms, his pictures can be fruitfully discussed and analysed within an international framework. In sum the "Good Keen Camera [man]" image needs to give way to a more expansive and nuanced one, which connects Cleveland to the aesthetic and intellectual realms where his work clearly belongs. 


\section{REFERENCES}

Amery, Mark. "Work is Life", NZ Listener (August 1, 1998): 40-41.

Barthes, Roland. Camera Lucida: Reflections on Photography, trans. Richard Howard. New York: Hill and Wang, 1981.

Belich, James. Making Peoples: a History of the New Zealanders from Polynesian Settlement to the end of the Nineteenth Century. Auckland: Penguin Books, 1996.

Benjamin, Walter. "The Work of Art in the Age of Mechanical Reproduction", in Illuminations, ed. Hannah Arendt, trans. Harry Zorn. London: Pimlico, 1999

Benjamin, Walter. "The Return of the Flâneur", in Walter Benjamin: Selected Writings, Volume 2, Part 1, 1927 - 1930, ed. Michael Jennings et al., trans. Rodney Livingstone et al. Cambridge, MA: Harvard University Press, 2005.

Bourdieu, Pierre. "Intellectual Field and Creative Project", trans. Sian France. Social Science Information, vol.8, no.2, (1969): 89 119.

Brasch, Charles. "Documentary". Landfall Country: Work from Landfall, 1947 -1961, ed. Charles Brasch, Christchurch: The Caxton Press, 1962.

Cleveland, Les. Letter to the Editor, Landfall, vol.17, no.2 (June 1963): 204

Cleveland, Les. “The New Zealand Experience - an Analysis of the Organic Tradition in New Zealand Fiction", unpublished MA research paper, Victoria University of Wellington, 1964

Cleveland, Les. The Silent Land. Christchurch: The Caxton Press, 1966.

Cleveland, Les. "William and Frederick Tyree - Photographers of Nelson and Collingwood", a memorandum dated September 29, 1966 Unpublished typescript, Alexander Turnbul Library, Wellington.

Cleveland, Les. "The Tyrees: Notes towards a Critical Assessment", PhotoForum Supplement (Spring 1979): 6-9.

Cleveland, Les. "The Harrowing of Te Aro: a Photo Essay", New Zealand Journal of Photography, no.47, (Winter 2002): 6-7.

Curnow, Allen (ed.). A Book of New Zealand Verse 1923 - 1945, Christchurch: The Caxton Press, 1945.

Curnow, Wystan. "Landscape and the Body", Antic, no.3 (November 1987): 143-163.

Eggleton, David. Into the Light: a History of

New Zealand Photography. Nelson: Craig

Potton, 2006.

Fearnley, Charles. Vintage Wellington. Dunedin: John McIndoe Ltd, 1970

"Focus on Hemlines", New Zealand Listener (August 28, 1959): 3 .

Herschdorfer, Nathalie (ed.). The Thames \& Hudson Dictionary of Photography. London: Thames \& Hudson, 2015.

Ireland, Peter. Review of Message from the Exterior. Landfall 197 (Autumn 1999): 129-133.

Ireland, Peter. "Les Cleveland (1921 - 2014)". Photoforum-nz.org

Jackson, Michael. "Remembering Les

Cleveland". Backstory, no.7, (December 2019): $5-23$

Johnson, Matt. "Snapshot of Six Decades" Sunday Star-Times, July 26, 1998, F3.
Lealand, Geoff. "Such a Modest Man: the Cultural Heritage of Les Cleveland". New Zealand Memories, no.143 (April-May 2020): 51-53.

Levinas, Emmanuel. Totality and Infinity: an Essay on Exteriority. Trans. by Alphonso Lingis. Pittsburgh: Dud

McCredie, Athol. "The Social Landscape", in Witness to Change: Life in New Zealand - John Pascoe Les Cleveland Ans Westra Photographs 1940 - 1965. Wellington: PhotoForum, 1985: 49-53.

McCredie, Athol. The New Photography: New Zealand's First-Generation Contemporary Photographers. Wellington: Te Papa Press, 2019

McDonald, Lawrence. "A Dwelling with Many Rooms: Les Cleveland's Construction of New Zealand Experience in Images, Words and Song", in Les Cleveland: Six Decades - Message from the Exterior, ed. Lawrence McDonald. Wellington: City Gallery, Wellington \& Victoria University Press 1998: 6-28.

McDonald, Lawrence \& Virginia Callanan Number 8 / Super 8: Amateur and Home Movie Making in New Zealand. Wellington: The Film Centre, 1995.

McPherson, Mary. "Photographer Presents View of Workers' Lives", The Dominion, September 26, 1998, 20

Morrison, Alistair. "Songs to Warm the Heart and the Billy", The Dominion October 19, 1991

Paton, Justin. "Slivers of Time". NZ Listener (October 3-9, 1998): 44-45.
Penman, Neil. Review of Message from the Exterior, New Zealand Journal of Photography n.34 (February 1999): 24.

Said, Edward. Representations of the Intellectual. London: Vintage, 1994

Schrader, Paul. Transcendental Style in Film Ozu, Bresson, Dreyer. Berkeley: University of California Press / Da Capo, 1972.

Sharp, lain. "Clever Cleveland's Captivating Images", Sunday Star-Times, August 16, 1998

Simmons, Laurence, Looking Back: Les Cleveland's Poetics of Documentation", in Les Cleveland: Six Decades - Message from the Exterior, ed. Lawrence McDonald. Wellington City Gallery, Wellington \& Victoria University Press 1998: 105-113.

Skinner, Damian. "Wellington". Art New Zealand, no.89 (Summer 1998/9): 27.

Thompson, Paul. "A Good Keen Camera". New Zealand Books (December 1998): 19

Trevelyan, Jill. Peter McLeavey: the Life and Times of a New Zealand Art Dealer. Wellington: Te Papa Press, 2013

Turner, John B. Eric Lee-Johnson: Artist with Camera. Auckland: PhotoForum Inc. 1999.

Turner, Peter. "After you with the Megaphone", New Zealand Journal of Photography, no.9, (November 1992): 6-7.

Turner, Peter. "Reflections", in Les Cleveland: Six Decades - Message from the Exterior, ed. Lawrence McDonald. Wellington: City Gallery, Wellington \& Victoria University Press 1998: 41-47.

Wentholt, Rob "A Choice of Worlds", Landfall, vol.16, no.4 (December 1962): 343-362. 


\section{END NOTES}

1. Most notably Michael Jackson's "Remembering Les Cleveland", Backstory, no.7, December 2019, 5-23, which stresses the importance of Cleveland's early wartime experience for his later endeavours. See also, Geoff Lealand, "Such a Modest Man: the Cultural Heritage of Les Cleveland", New Zealand Memories, no.143, April-May 2020, 51-53.

2. Peter Ireland, "Les Cleveland (1921 2014)", Photoforum-nz.org

3. Athol McCredie, "The Social Landscape", in Witness to Change: Life in New Zealand - John Pascoe, Les Cleveland, Ans Westra Photographs 1940 - 1965 (Wellington: PhotoForum 1985), 49

4. The soundtrack consisted of three song from The Songs We Sang by Les Cleveland and the D-Day Dodgers (1959): "The Quartermaster's Store"; "The Lousy Lance Corporal"; and "The Dugout in Matruh".

5. The working title for the project, which appeared on the cover sheet of the proposal submitted in March 1996, was "Vernacular cons: Les Cleveland Photographs".

Subsequently, I changed the title of the project to Les Cleveland: Six Decades Message from the Exterior.

6. A consequence of the success of this application and the subsequent co-publishing partnership with Victoria University Press was that the gallery decided not to proceed with the brochure, which was to have taken the form of an interview with Les Cleveland conducted by me.

7. Lawrence McDonald, "A Dwelling with Many Rooms: Les Cleveland's Construction of New Zealand Experience in Images, Words and Song", in Les Cleveland: Six Decades - Message from the Exterior, ed.
Lawrence McDonald (Wellington: City Gallery, Wellington \& Victoria University Press 1998),

8. Peter Turner, "Reflections", in ibid., 41-47.

9. Laurence Simmons, "Looking Back: Les Cleveland's Poetics of Documentation", in ibid., 105-113.

10. Pierre Bourdieu, "Intellectual Field and Creative Project", trans. Sian France, Social Science Information, vol 8, no. 2, 1969,107, 105

11. Eric Lee-Johnson, cited in John B. Turner, Eric Lee-Johnson: Artist with a Camera (Auckland: PhotoForum Inc. 1999), 8.

12. David Eggleton, Into the Light: a History of New Zealand Photography (Nelson: Craig Potton, 2006), 76.

13. Les Cleveland, "The New Zealand Experience - an Analysis of the Organic Tradition in New Zealand Fiction", unpublished MA research paper, Victoria University of Wellington, 1964.

14. Les Cleveland, Letter to the Editor, Landfall, vol.17, no.2, June 1963, 204. Cleveland wrote this letter in response to Rob Wentholt, "A Choice of Worlds", Landfall, vol.16, no.4, December 1962, 343-362.

15. Les Cleveland, The Silent Land (Christchurch: The Caxton Press, 1966).

16. Les Cleveland, "The Tyrees: Notes towards a Critical Assessment", PhotoForum Supplement, spring 1979, 7,8

17. Charles Brasch, "Documentary", in Landfall Country: Work from Landfall, 1947 1961, ed. Charles Brasch (Christchurch: The Caxton Press, 1962), 447.
18. Bourdieu, 116

19. Walter Benjamin, "The Work of Art in the Age of Mechanical Reproduction", in Illuminations, ed. Hannah Arendt, trans. Harry Zorn (London: Pimlico, 1999), 219.

20. Eggleton, 76.

21. Ibid. This statement echoes an earlier one by Wystan Curnow who writes that The Silent Land "takes its title from Charles Brasch's well-known poem of that name". See Wysta Curnow, "Landscape and the Body", Antic, no.3, November 1987, 147

22. Les Cleveland, cited in Athol McCredie, "The Social Landscape", in Witness to Change: Life in New Zealand - John Pascoe Les Cleveland, Ans Westra Photographs 1940 1965 (Wellington: PhotoForum 1985), 49.

23. My access to this poem is via $A B$ Book of New Zealand Verse 1923 - 1945, ed. Allen Curnow (Christchurch: The Caxton Press, 1945), 149.

24. McDonald, 10-19

25. Paul Thompson, "A Good Keen Camera", New Zealand Books, December 1998, 19

26. Neil Penman, Review of Message from the Exterior, New Zealand Journal of Photography, no.34, February 1999, 24.

27. Justin Paton, "Slivers of Time", NZ Listener, October 3-9, 1998, 44

28. Peter Ireland, Review of Message from the Exterior, Landfall 197, Autumn 1999, 132.

29. Damian Skinner, "Wellington", Art New Zealand, no.89, Summer 1998/9, 27.

30. McDonald, 11-12
31. Les Cleveland, “William and Frederick Tyree - Photographers of Nelson and Collingwood", a memorandum dated September 29, 1966. Unpublished typescript Alexander Turnbull Library, Wellington.

32. Les Cleveland, "The Tyrees: Notes towards a Critical Assessment", PhotoForum Supplement, spring 1979, 6. The first two concepts persist in the theoretical approach of the first volume of James Belich's history of New Zealand, but in place of the third he advances the "ethos of expansion", which he applies to both Polynesian and European colonizing initiatives. See James Belich, Making Peoples: a History of the New Zealanders from Polynesian Settlement to the end of the Nineteenth Century (Auckland: Penguin Books, 1996), 37-38.

33. Iain Sharp, "Clever Cleveland's Captivating Images", Sunday Star-Times, August 16, 1998, F4.

34. Mary McPherson, "Photographer Presents View of Workers' Lives", The Dominion, September 26, 1998, 20.

35. Les Cleveland quoted in Matt Johnson "Snapshot of Six Decades", Sunday StarTimes, July 26, 1998, F3.

36. Walter Benjamin, "The Return of the Flâneur", in Walter Benjamin: Selected Writings, Volume 2, Part 1, 1927 - 1930 ed. Michael Jennings et al., trans. Rodney Livingstone et al. (Cambridge, MA: Harvard University Press, 2005), 262-3.

37. Although these photographs were all taken between 1938 and 1941, it was not until 1966 that they were exhibited publicly at The Museum of Modern Art, New York, accompanied by a book with an essay by James Agee (written in 1940), the title of which also served as the book's title: 


\section{END NOTES}

Many Are Called. For a reproduction of this photograph see Gilles Mora and John T.Hill,

Walker Evans: The Hungry Eye (London:

Thames and Hudson, 2004): 227.

38. Charles Fearnley, Vintage Wellington (Dunedin: John Mclndoe Ltd, 1970). This book is a "companion volume" to another McIndoe publication, Victorian City of New Zealand (1968), a study of Dunedin architecture, which pairs architect Ted McCoy's text with the photographs of Gary Blackman.

39. Les Cleveland, "The Harrowing of $\mathrm{Te}$ Aro: a Photo Essay", New Zealand Journal of Photography, no.47, Winter 2002, 6-7.

40. Jill Trevelyan, Peter McLeavey: the Life and Times of a New Zealand Art Dealer Wellington: Te Papa Press, 2013), 379.

41. Alistair Morrison, "Songs to Warm th Heart and the Billy", The Dominion October $19,1991,9$

42. The list is extensive and includes the following items: the title of Paul Thompson's review of Message ("A Good Keen Camera", New Zealand Books, December 1998, 19); Matt Johnson's reference to a "feather in the Swandri cap of this good keen man with a PhD" (Matt Johnson, "Snapshot of Six Decades", Sunday Star-Times, July 26, 1998 F3); and Mark Amery's two variations on the theme - "The Barry Crump of photography" and "... a thinking man's Barry Crump" (Mark Amery, "Work is Life", NZ Listener, August 1 , $1998,40,41)$.

43. Paul Schrader, Transcendental Style in Film: Ozu, Bresson, Dreyer (Berkeley: University of California Press / Da Capo, 1972), 8
44. Emmanuel Levinas, Totality and Infinity: an Essay on Exteriority, trans. Alphonso Lingis (Pittsburgh: Duquesne University Press, 1969), 201

45. Furthermore, I would draw attention to a remarkable scene in Vivre Sa Vie wherein Nana (Anna Karina) attends a screening of La Passion de Jeanne d'Arc and the director cuts between close ups of her tearful face and Joan's (Maria Falconetti).

46. "Focus on Hemlines", New Zealand Listener, August 28, 1959, 3.

47. Edward Said, Representations of the Intellectual (London: Vintage, 1994), 57. For his part, Roland Barthes is clear that "... in the field of photographic practice, it is the amateur ... who stands closer to the noeme of photography." Roland Barthes, Camera Lucida: Reflections on Photography, trans. Richard Howard (New York: Hill and Wang 1981), 99.

48. The photograph in question is "Old Presbyterian Church, Watt St, Wanganui, occupied by S. (Skin) Hackett, radiator repair expert 1957".

49. Peter Turner, "After you with the

Megaphone", New Zealand Journal of Photography, no.9, November 1992, 7. Twentythree years after he asked this question, five New Zealand photographers were included in a large reference work published by Thames \& Hudson, but Cleveland was not one of them. The photographers are: the Burton Brothers, Laurence Aberhart, Brian Brake, Anne Noble, and Peter Peryer. See The Thames \& Hudson Dictionary of Photography, ed. Nathalie Herschdorfer (London: Thames \& Hudson, 2015)

50. Peter Turner quoted in Mark Amery

"Work is Life", NZ Listener, August 1, 1998, 41. 